\title{
Acid Foods and Soft Drinks Dental Erosive Potential: Warning Messages or Not?
}

\author{
Potencial Erosivo Dental de Alimentos Ácidos y Bebidas No Alcohólicas: \\ ¿Existen Mensajes de Advertencia?
}

\author{
Mauro Elias Mesko*; Jovito Adiel Skupien"* \& Tatiana Pereira-Cenci"*
}

MESKO, M. E.; SKUPIEN, J. A. \& PEREIRA-CENCI,T. Acid foods and soft drinks dental erosive potential: Warning messages or not? Int. J. Odontostomat., 8(1):59-62, 2014.

ABSTRACT: This Communication aims to present the issue of dental erosion in another point of view. Considering the increasing rate of incidence of this dental injury among children and adults, the narrative raises the question about the danger of indiscriminate intake of certain acidic foods and beverages which are scientifically proven as one of the causes of dental erosion, as well as the complete neglect of information by the food industry about these products. The authors present some points that still remain in doubt in this topic and some approaches, which should be taken to alert the population about the relation between acidity of food and dental erosion.

KEY WORDS: tooth erosion, acidity, food Industry, eating.

\section{INTRODUCTION}

Epidemiological studies have shown that there has been an important increase of dental erosion in some populations in recent years (Nunn et al., 2003; Correr et al., 2009; Arnadottir et al., 2010; Kreulen et al., 2010). Some authors suggest that acidic foods and beverages may be responsible for the assault on dental surface and surface erosion (Barbour et al., 2011; El Aidi et al., 2011; Ligh et al., 2011). It is not possible to establish its direct cause and effect relationship because of multifactorial causes (Nunn et al.; Arnadottir et al.; El Aidi et al.; Lussi et al., 2012). However, some factors have been cited as risk factors to erosion (Barbour et al.; Bartlett et al., 2011; El Aidi et al.).

Taking in account that teeth will be in service for longer time, as a result of preventive efforts, their structures need to be more resistant to function through the individual's lifespan (Müller et al., 2007). Furthermore, gingival recession is a very common finding in older adults and tends to be a problem because dental root tissues are softer than enamel making them more vulnerable to bacterial, mechanical and chemical attack (Bartlett, 2007).
Saliva is a natural protection for dental erosion in the same way it is to dental demineralization caused by bacteria in case of dental caries. Oral environment is capable to recover its natural neutral $\mathrm{pH}$ after ingestion of acidic substances (Millward et al., 1997; Wang \& Lussi, 2010). This mechanism needs some time for $\mathrm{pH}$ recovering, so it is prudent to avoid further damage, waiting about 30 minutes until teeth brushing is performed - as a way to prevent a symbiotic effect of chemical softening of dental tissues and mechanical attrition of tooth paste and dental brush (Attin et al., 2004). Additionally, a diet with a less than critical pH will cause demineralization and can jeopardize the recovery process even further. It is established in the literature there are several foods that may induce dental erosion (Ligh et al.).

A way to artificially protect teeth is high doses of fluoride (Ligh et al.). Some foods have the potential to prevent dental erosion (El Aidi et al.). Enamel protection of this injury is possible and some studies indicate that high fluoride doses can prevent erosion of the tooth's crown but the same does not occur with two other tooth tissues: cement and dentin (Schlueter et al., 2009).

* Graduate Program in Dentistry, Federal University of Pelotas, Pelotas, Brazil.

* PhD Student, Graduate Program in Dentistry, Federal University of Pelotas, Pelotas, Brazil.

${ }^{* * *}$ Professor, Graduate Program in Dentistry, Federal University of Pelotas, Pelotas, Brazil. 
Studies performed to evaluate erosion disagree in their results mainly because there is not only a widely accepted way to access this clinical problem and therefore this direct relation cannot be stated even for clinical evaluation of large populations (Donachie \& Walls, 1996; Young et al., 2008; Ganss et al., 2011; Margaritis et al., 2011; Wiegand \& Attin, 2011).

Dentistry is a science in evolution and great efforts have been made for replacement of dental tissues lost by caries, fractures or erosion, this substitution is not perfect, has a limited lifetime and it can be expensive, mainly in cases where this loss occurred in large extents, as frequently occurs in cases of severe erosion and tooth wear (Gulamali et al., 2011; Hamburguer et al., 2011; Katsoulis et al., 2011).

It has been suggested that in some countries the ingestion of drinks with low $\mathrm{pH}$ has been increasing (Coppinger et al., 2011; Gambon et al., 2011; Okunseri et al., 2011, Duffey et al., 2012). The food industry is trying to modify and improve products in a way to cause less injury to dental tissues, but addition of substances to elevate the $\mathrm{pH}$ of some food and drink can modify the original taste, stability or may cause lifetime reduction, jeopardizing this process. Meanwhile, it is important to report that many other factors can enhance the erosive process, like stomach problems, bulimia nervosa and parafunction (Bartlett; Barbour et al.; Bartlett et al.; El Aidi et al.; Ligh et al.).

Elderly individuals tend to have tooth wear losses (Burke \& McKenna, 2011). In modern lifestyle where fast food and soft drinks are frequently consumed, in the worst case, many of these individuals nowadays have an almost exclusive, frequent or excessive ingestion of this type of food, without any prevention and their teeth will probably be easily damaged.

The remaining question is: if these products can cause dental damage, is it not necessary for the food industry to alert its consumers about possible risks of consuming these products in excess?

The industrial problem. The argument that naturally acidic foods can cause dental damage is used by the food industry as a way to defend its interests in not disclaiming the products.

Tracing a parallel discussion, some countries made mandatory the print on some product's labels that processed cow's milk cannot be the only source of dairy nutrition. However, many people are still consuming raw unlabeled cow's milk. This fact does not change the industry's obligation to alert the population about the cited risk.

Another example occurs in the cigarette labeling process with tobacco warning messages, (ICAP, 2008; Hammond, 2011) where, despite many people in rural zones continue to smoke hand-made cigarettes, there are no warning labels. Nowadays, it is not permitted to link sports and cigarettes; regardless this was not forbidden in a recent past. Television campaigns about tobacco products in some countries are still permitted, but messages about its side effects always appear at the end of advertisements.

Well established politics exists to alert about excesses in alcohol intake. It passes by community evaluation (ICAP). Another very interesting example happened in the United Kingdom where: "Consultation on options for improving information on the labels of alcoholic drinks to support consumers to make healthier choices in the UK" in May 2010 and the respective establishment of politics in 2011. Some incipient efforts are relative to food and beverages, but it still does not address consumer information on the product label, neither does it alert about dental erosion risks (Alexander et al., 2011). On the other hand, the media does not inform clearly about the risks of beverages (Bonfiglioli et al., 2011). Dental associations are starting campaigns against soft drinks but they are not massive. Therefore, if acidic foods and soft drinks are not as innocuous as they seem, why not alert people about the probable side effects of consuming excess industrialized acidic food or beverages with warning messages on the label? The answer falls on the problem of controversial topics in healthcare. To solve it, science must improve its survey methods regarding dental erosion and find a way of asking the right questions in order to receive the best answers, in an Evidence Based Practice approach in this controversial field.

MESKO, M. E.; SKUPIEN, J. A. \& PEREIRA-CENCI,T. Potencial erosivo dental de alimentos ácidos y bebidas no alcohólicas: ¿Existen mensajes de advertencia? Int. J. Odontostomat., 8(1):59-62, 2014.

RESUMEN: El objetivo del presente estudio es abordar el tema de la erosión dental desde otro punto de vista. Al tener en cuenta la creciente tasa de incidencia de esta lesión dental en niños y adultos, el trabajo plantea la pregunta sobre el peligro de la ingesta indiscriminada de ciertos alimentos ácidos y bebidas que han sido identificados científi- 
camente como una de las causas de la erosión dental, como asimismo, una completa falta de información por parte la industria alimentaria sobre estos productos. Se presentan algunos puntos que aún quedan en duda referente a este tema y algunos enfoques que se deben tomar para alertar a lapoblación acerca de la relación entre la acidez de los alimentos y la erosión dental.

PALABRAS CLAVE: erosión dental, acidez, industria de alimentos, comer.

\section{REFERENCES}

Alexander, E.; Yach, D. \& Mensah, G. A. Major multinational food and beverage companies and informal sector contributions to global food consumption: implications for nutrition policy. Global Health, 7:26, 2011.

Arnadottir, I. B.; Holbrook, W. P.; Eggertsson, H.; Gudmundsdottir, H.; Jonsson, S. H.; Gudlaugsson, J. O.; Saemundsson, S. R.; Eliasson, S. T. \& Agustsdottir, H. Prevalence of dental erosion in children: a national survey. Community Dent. Oral Epidemiol., 38(6):521-6, 2010.

Attin, T.; Siegel, S.; Buchalla, W.; Lennon, A. M.; Hannig, C. \& Becker, K. Brushing abrasion of softened and remineralised dentin: an in situ study. Caries Res., 38(1):62-6, 2004

Barbour, M. E.; Lussi, A. \& Shellis, R. P. Screening and prediction of erosive potential. Caries Res., 45(Suppl. 1):24-32, 2011.

Bartlett, D. A new look at erosive tooth wear in elderly people. J. Am. Dent. Assoc., 138(Suppl.):21S-5S, 2007.

Bartlett, D. W.; Fares, J.; Shirodaria, S.; Chiu, K.; Ahmad, N. \& Sherriff, M. The association of tooth wear, diet and dietary habits in adults aged $18-30$ years old. J. Dent., 39(12):811-6, 2011.

Bonfiglioli, C.; Hattersley, L. \& King, L. Australian print news media coverage of sweet, non-alcoholic drinks sends mixed health messages. Aust. N. Z. J. Public Health, 35(4):325-30, 2011.

Burke, F. M. \& McKenna, G. Toothwear and the older patient. Dent. Update, 38(3):165-8, 2011.

Coppinger, T.; Jeanes, Y.; Mitchell, M. \& Reeves, S. Beverage consumption and BMl of British schoolchildren aged 9-13 years. Public Health Nutr., 16(7):1244-9, 2013.
Correr, G. M.; Alonso, R. C.; Correa, M. A.; Campos, E. A.; Baratto-Filho, F. \& Puppin-Rontani, R. M. Influence of diet and salivary characteristics on the prevalence of dental erosion among 12-year-old schoolchildren. J. Dent. Child. (Chic.), 76(3):181-7, 2009.

Donachie, M. A. \& Walls, A. W. The tooth wear index: a flawed epidemiological tool in an ageing population group. Community Dent. Oral Epidemiol., 24(2):152-8, 1996.

Duffey, K. J.; Huybrechts, I.; Mouratidou, T.; Libuda, L.; Kersting, M.; De Vriendt, T.; Gottrand, F.; Widhalm, K.; Dallongeville, J.; Hallström, L.; González-Gross, M.; De Henauw, S.; Moreno, L. A.; Popkin, B. M. \& HELENA Study group. Beverage consumption among European adolescents in the HELENA study. Eur. J. Clin. Nutr., 66(2):244-52, 2012.

El Aidi, H.; Bronkhorst, E. M.; Huysmans, M. C. \& Truin, G. J. Multifactorial analysis of factors associated with the incidence and progression of erosive tooth wear. Caries Res., 45(3):303-12, 2011.

Gambon, D. L.; Brand, H. S.; Boutkabout, C.; Levie, D. \& Veerman, E. C. Patterns in consumption of potentially erosive beverages among adolescent school children in the Netherlands. Int. Dent. J., 61(5):247-51, 2011.

Ganss, C.; Young, A. \& Lussi, A. Tooth wear and erosion: methodological issues in epidemiological and public health research and the future research agenda. Community Dent. Health, 28(3):191-5, 2011.

Gulamali, A. B.; Hemmings, K. W.; Tredwin, C. J. \& Petrie, A. Survival analysis of composite Dahl restorations provided to manage localised anterior tooth wear (ten year followup). Br. Dent. J., 211(4):E9, 2011.

Hamburger, J. T.; Opdam, N. J.; Bronkhorst, E. M.; Kreulen, C. M.; Roeters, J. J. \& Huysmans, M. C. Clinical performance of direct composite restorations for treatment of severe tooth wear. J. Adhes. Dent., 13(6):585-93, 2011.

Hammond, D. Health warning messages on tobacco products: a review. Tob. Control, 20(5):327-37, 2011.

International Center for Alcohol Policies (ICAP). Guide to creating integrative alcohol policies. Washington DC, International Center for Alcohol Policies, 2008.

Katsoulis, J.; Nikitovic, S. G.; Spreng, S.; Neuhaus, K. \& Mericske-Stern, R. Prosthetic rehabilitation and treatment outcome of partially edentulous patients with severe tooth wear: 3-years results. J. Dent., 39(10):662-71, 2011.

Kreulen, C. M.; Van 't Spijker, A.; Rodriguez, J. M.; Bronkhorst, E. M.; Creugers, N. H. \& Bartlett, D. W. Systematic review of the prevalence of tooth wear in children and adolescents. Caries Res., 44(2):151-9, 2010. 
MESKO, M. E.; SKUPIEN, J. A. \& PEREIRA-CENCI,T. Acid foods and soft drinks dental erosive potential: Warning messages or not? Int. J. Odontostomat., 8(1):59-62, 2014.

Ligh, R. Q.; Fridgen, J. \& Saxton, C. The effect of nutrition and diet on dental structure integrity. J. Calif. Dent. Assoc., 39(4):243-9, 2011.

Lussi, A.; Megert, B.; Shellis, R. P. \& Wang, X. Analysis of the erosive effect of different dietary substances and medications. Br. J. Nutr., 107(2):252-62, 2012.

Margaritis, V.; Mamai-Homata, E. \& Koletsi-Kounari, H. Novel methods of balancing covariates for the assessment of dental erosion: a contribution to validation of a synthetic scoring system for erosive wear. J. Dent., 39(5):361-7, 2011.

Millward, A.; Shaw, L.; Harrington, E. \& Smith, A. J. Continuous monitoring of salivary flow rate and $\mathrm{pH}$ at the surface of the dentition following consumption of acidic beverages. Caries Res., 31(1):44-9, 1997.

Müller, F.; Naharro, M. \& Carlsson, G. E. What are the prevalence and incidence of tooth loss in the adult and elderly population in Europe? Clin. Oral Implants Res., 18(Suppl. 3):2-14, 2007.

Nunn, J. H.; Gordon, P. H.; Morris, A. J.; Pine, C. M. \& Walker, A. Dental erosion -- changing prevalence? A review of British National childrens' surveys. Int. J. Paediatr. Dent., 13(2):98-105, 2003.

Okunseri, C.; Okunseri, E.; Gonzalez, C.; Visotcky, A. \& Szabo, A. Erosive tooth wear and consumption of beverages among children in the United States. Caries Res., 45(2):130-5, 2011.

Schlueter, N.; Klimek, J. \& Ganss, C. Efficacy of an experimental tin-F-containing solution in erosive tissue loss in enamel and dentine in situ. Caries Res., 43(6):415-21, 2009.

Young, A.; Amaechi, B. T.; Dugmore, C.; Holbrook, P.; Nunn, J.; Schiffner, U.; Lussi, A. \& Ganss, C. Current erosion indices--flawed or valid? Summary. Clin. Oral Investig., 12(Suppl. 1):S59-63, 2008.

Wang, X. \& Lussi, A. Assessment and management of dental erosion. Dent. Clin. North Am., 54(3):565-78, 2010.

Wiegand, A. \& Attin, T. Design of erosion/abrasion studies-insights and rational concepts. Caries Res., 45(Suppl. 1):53-9, 2011.
Correspondence to:

Jovito Adiel Skupien

R. Gonçalves Chaves 457

Pelotas, RS, 96015-560

BRAZIL

Tel/Fax: 32256741 ext. 134

Email: skupien.ja@gmail.com

Received: 23-08-2013

Accepted: 24-01-2014 